\title{
Experimental verification of a CFD model intended for the determination of restitution coefficients used in erosion modelling
}

\author{
Bartlomiej Hernik ${ }^{1, *}$, Marek Pronobis $^{1}$, Robert Wejkowski ${ }^{1}$, and Wactaw Wojnar $^{1}$ \\ ${ }^{1}$ Silesian University of Technology, Division of Boilers and Steam Generators, Konarskiego 20, 44-100 Gliwice, Poland
}

\begin{abstract}
Erosion caused by solid particles transported with the steam or flue gas has a negative impact on the power unit reliability and availability. The erosion rate depends inter alia on the restitution of the particle velocity upon impact. The restitution coefficients determine the angle of the particle reflection off the tube surface and the particle post-impingement velocity, i.e., they determine the direction of the particle path, which has a substantial impact on the erosion phenomenon inside the tube. An attempt is made herein to develop a method of determination of restitution coefficients by means of numerical modelling assisted by experimental testing on physical models that will be implemented further in the Ansys Fluent code. Such a numerical procedure will verify the model of erosion caused by particles of iron oxides. The erodent impingement angle $\alpha_{l}$, the impingement velocity $w_{l}$, and the reflection velocity $w_{2}$ are measured using the Casio High-Speed Exilim EX-F1 camera, which enables filming at a high rate. The film is then processed graphically for "frame-by-frame" tracking. The following erodents were used in the testing: iron oxides, quartz sand with a different grain size $(490,1000,1500,2000 \mu \mathrm{m})$, and $1000 \mu \mathrm{m}$-diameter steel balls. The steel balls, due to their ideal shape, were treated as the comparative analysis reference standard. Erosion of three types of $5 \times 10 \mathrm{~cm}$ plates was tested: a plasma-coated plate with an anti-erosion layer, an aluminium plate; and a steel sheet plate. Based on the restitution coefficient testing results, numerical simulations were performed of the particle reflection off the surface.
\end{abstract}

\section{Introduction}

Erosion losses in the boiler elements such as the heat exchanger tube banks located on the path of dust-laden flue gas have a considerable negative impact on the power unit reliability and availability. Erosion processes usually have a local character, that is, there are cases where on the same tube bank, some areas remain completely unaffected by them, whereas in others, the wall thickness gets close to the permissible limit value.

Erosion caused by solid particles transported with the steam may also occur inside tubes as well as in turbines. The stability of oxide layers on the inner surfaces of superheater tubes may be disturbed due to exfoliation or spallation of iron oxides. Because of changes in the tube temperature during boiler operation, stress arises in the oxide layers, causing their exfoliation. This phenomenon can be observed in superheaters and reheaters made both of low-chromium ferritic and high-alloyed austenitic steels [1-3]. Erosion depends on many factors, including the particle kinetic energy on impingement, the impingement angle, the mechanical properties of the erodent and of the material with which the erodent comes into contact, and the restitution of the particle post-impingement velocity. In case of two-phase gassolid flows the rate of erosion and the restitution coefficients depend on the concentration of solid phase in the flow also.

\section{Numerical studies on the determination of restitution coefficients}

The process of accumulation of oxide layers on the inner surface of superheater tubes is disturbed in high steam temperatures because of exfoliation of oxides. Fig. 1 [Bląd! Nie zdefiniowano zakladki.] shows the result of such processes - the faults caused by the detachment of deposit fragments.

A correct simulation of the superheated steam twophase flow with particles of iron oxides that takes account of the particle reflection off the tube wall cannot be performed without the knowledge of restitution coefficients. The coefficients determine the angle of the particle reflection off the tube surface and the particle post-impingement velocity, i.e., they determine the direction of the particle path, which has a substantial impact on the erosion phenomenon inside the tube.

The erosion rate and the velocity of particles (usually considered to be identical to the carrier gas velocity) are related by an exponential dependence [4-8]. Reference literature includes numerous works devoted to the problem of damage done to tubes by fly ash carried by flue gas. However, the erosion of the power unit elements caused by particles of iron oxides separated from the inner surface of the superheater/reheater tube walls due to exfoliation and carried by steam has not

* Corresponding author: bartlomiej.hernik@polsl.pl 
been investigated in detail. An attempt is made herein to develop a method of determination of restitution coefficients by means of numerical modelling assisted by results of experimental testing on physical models that will be implemented further in the Ansys Fluent code [9]. Such a numerical procedure will verify the model of erosion caused by particles of iron oxides.

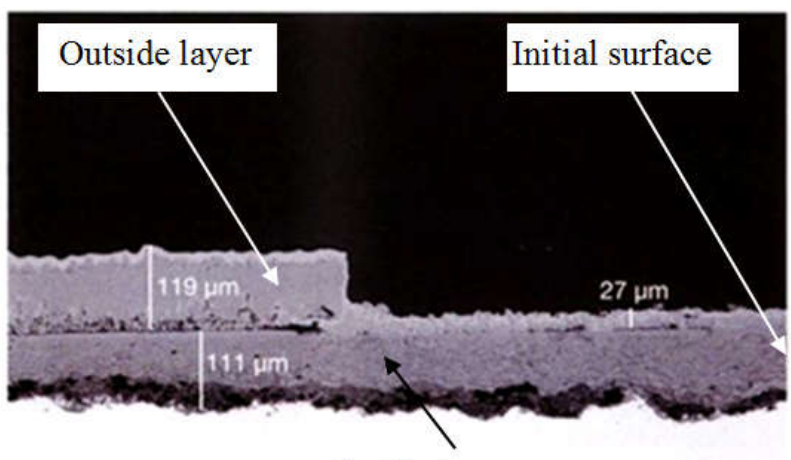

Inside layer

Fig. 1The cross-section through oxide layers on a tube made of P92 steel $(9 \%$ of $\mathrm{Cr})$ after $6200 \mathrm{~h}$ in steam with a temperature of $650^{\circ} \mathrm{C}$ [Błąd! Nie zdefiniowano zakładki.].

\subsection{Description of the reflection model used in the Ansys Fluent code}

Numerical simulations make it possible to define the flow profile for the working medium and the erodent. They are also a source of information on the erodent particle inflow velocities in the area of erosion. The calculations were performed using the Ansys Fluent code and taking account of modifications based on physical experiments.

In order to make a precise prediction of trajectories of the erodent particles after their reflection off the surface, it is necessary to apply a reflection model, which involves the use of restitution coefficients $e_{t}$ and $e_{n}$. The reduction in the reflection velocity compared to the impingement velocity is the effect of the erodent loss of kinetic energy. There is a direct relation between the difference in the system pre- and post-impingement kinetic energy and the erosion process intensity.

The coefficients are determined by measuring the erodent impingement angle $\alpha_{I}$ to the eroded surface and by measuring the erodent impingement and reflection velocities: $w_{1}$ and $w_{2}$, respectively, (cf. Fig. 2 ).

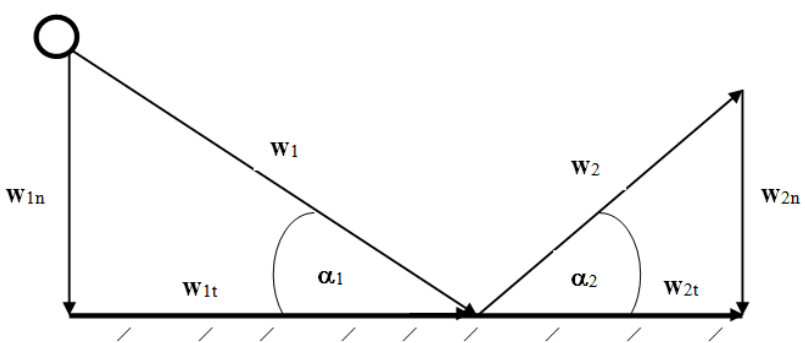

Fig. 2 Diagram of the particle reflection for boundary conditions of the restitution coefficient.

The normal restitution coefficient is defined as

$$
\boldsymbol{e}_{n}=\frac{w_{2 n}}{w_{1 n}}=\frac{w_{2} \sin \alpha_{2}}{w_{1} \sin \alpha_{1}}
$$

whereas the tangential coefficient is

$$
e_{t}=\frac{w_{2 t}}{w_{1 t}}=\frac{w_{2} \cos \alpha_{2}}{w_{1} \cos \alpha_{1}}
$$

where:

$w_{l}$ - impingement velocity,

$w_{1}$ - reflection velocity,

$\alpha_{1}$ - impingement angle,

$\alpha_{2}$ - reflection angle,

$w_{n}$ - normal-to-surface velocity component,

$w_{t}$ - tangential-to-surface velocity component,

$e_{n}$ - normal restitution coefficient, defined as the sum of momentum generated by the particle in the normal direction to the surface,

$e_{t}-$ tangential restitution coefficient, defined as the sum of momentum generated by the particle in the tangential direction to the surface.

A normal or tangential restitution coefficient of 1 means that after the reflection the normal or tangential momentum of the particle is conserved (perfectly elastic collision), a coefficient equal to 0 means a perfect plastic collision (inelastic collision). In reality, for a real elasticplastic collision, the coefficient value is included in the following interval: $0<e<1$. Studies indicate that the erodent particle impingement angle has a decisive effect on the restitution coefficient values. Restitution coefficients have an indirect impact on the erosion rate calculation results even though they do not appear directly in the erosion model used in this code. The Fluent code restitution coefficients determine the properties of the material with respect to its capacity to reflect the particle. Different correlations are put forward in the literature to describe restitution coefficients [Bląd! Nie zdefiniowano zakładki., 10-13].

\subsection{Description of the erodent and the testing stand}

The erosion testing stand is presented in Fig. 3. The erodent-transporting medium is air pressurized in a compressor to about 5 bar.

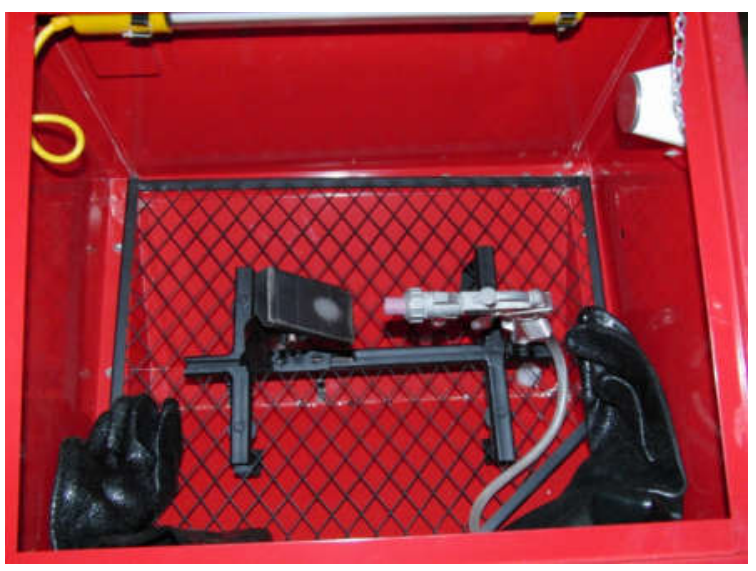

Fig. 3 Erosion testing stand.

The plate subjected to the erodent effect is set at an angle of $45^{\circ}$, which is typical in erosion testing of ductile 
metals (at this angle the material loss is the greatest). The erodent impingement angle $\alpha_{1}$, the impingement velocity $w_{1}$, and the reflection velocity $w_{2}$ are measured using the High-Speed Exilim EX-F1 camera made by Casio, which enables filming at a high rate. The film is then processed graphically for "frame-by-frame" tracking. Three types of $5 \times 10 \mathrm{~cm}$ plates were tested:

- a plasma-coated plate with an anti-erosion layer,

- an aluminium plate,

- a steel sheet plate.

The following erodents were used in the testing: iron oxides, quartz sand with a various grain size, and 1.0 mm-diameter steel balls. This enabled a comparison between a monodispersed erodent with a perfect geometry and two polydispersed ones with different density and hardness values. Quartz density is 2.65 $\mathrm{g} / \mathrm{cm}^{3}$ with hardness 7 in Mohs' scale, whereas for haematite and magnetite these values range from 4.9 to $5.3 \mathrm{~g} / \mathrm{cm}^{3}$ and from 5.5 to 6.5 . Iron oxides are taken into consideration due to possible occurrence of exfoliation in the steam superheater tubes, which disturbs the stability of oxide layers on the tubes' inner surfaces.

Because it was impossible to obtain real iron oxides separated from steam superheaters, rust particles collected from steel elements were used for the erosion testing (Fig. 4).

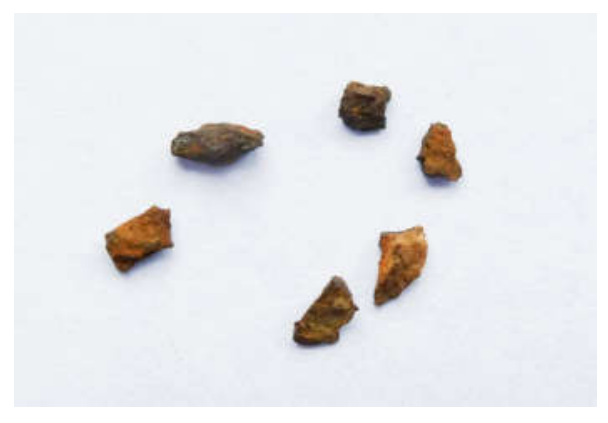

Fig. 4 Example particles of iron oxides

Their composition was determined using a scanning electron microscope equipped with an energy dispersive $\mathrm{X}$-ray spectrometer (the SEM EDS method).

Considering atomic masses of oxygen and iron and the oxide formula for three possible iron oxides, the following proportions of masses and atomic numbers listed in Table 1 are obtained (mass content $-\mathrm{Wt} \%$ column, atomic content $-\mathrm{At} \%$ column):

Table 1. Mass and atomic contents of oxygen and iron in oxides.

\begin{tabular}{|l|c|c|c|c|}
\hline \multirow{2}{*}{ Oxide } & \multicolumn{2}{|c|}{ Fe content } & \multicolumn{2}{c|}{ O content } \\
\cline { 2 - 5 } & $\begin{array}{c}\text { Mass } \\
\text { content } \\
\text { Wt\% }\end{array}$ & $\begin{array}{c}\text { Atomic } \\
\text { content } \\
\text { At\% }\end{array}$ & $\begin{array}{c}\text { Mass } \\
\text { content } \\
\text { Wt\% }\end{array}$ & $\begin{array}{c}\text { Atomic } \\
\text { content } \\
\text { At\% }\end{array}$ \\
\hline Wustite $\quad \mathrm{FeO}$ & 77.78 & 50.00 & 22.22 & 50.00 \\
\hline Haematite $\mathrm{Fe}_{2} \mathrm{O}_{3}$ & 70.00 & 40.00 & 30.00 & 60.00 \\
\hline Magnetite $\mathrm{Fe}_{3} \mathrm{O}_{4}$ & 72.41 & 42.86 & 27.59 & 57.14 \\
\hline
\end{tabular}

Table 2 presents the results of SEM EDS measurements for three samples of rust particles and the corrected results after elimination of small $\mathrm{Al}$ and $\mathrm{Si}$ admixtures and conversion to contents of iron and oxygen only.

Table 2. EDS results (atomic proportions) for 3 samples and their correction after conversion to contents of $\mathrm{Fe}$ and $\mathrm{O}$ only. $\mathrm{M}$ means Measurement and $\mathrm{C}$ means Correction.

\begin{tabular}{|c|c|c|c|c|c|c|}
\hline \multirow{2}{*}{ Element } & \multicolumn{2}{|c|}{$\begin{array}{c}\text { Sample } \\
\text { MP1-1 }\end{array}$} & \multicolumn{2}{c|}{$\begin{array}{c}\text { Sample } \\
\text { MP1-2 }\end{array}$} & \multicolumn{2}{c|}{$\begin{array}{c}\text { Sample } \\
\text { MP1-3 }\end{array}$} \\
\cline { 2 - 7 } & $\mathbf{M}$ & $\mathbf{C}$ & $\mathbf{M}$ & $\mathbf{C}$ & $\mathbf{M}$ & $\mathbf{C}$ \\
\hline $\mathrm{O}$ & 57.73 & 58.86 & 53.5 & 54.53 & 60.67 & 61.47 \\
\hline $\mathrm{Al}$ & 0.89 & 0.00 & 0.64 & 0.00 & 0.77 & 0.00 \\
\hline $\mathrm{Si}$ & 1.03 & 0.00 & 1.24 & 0.00 & 0.53 & 0.00 \\
\hline $\mathrm{Fe}$ & 40.35 & 41.14 & 44.62 & 45.47 & 38.04 & 38.54 \\
\hline Total & 100 & 100 & 100 & 100 & 100 & 100 \\
\hline
\end{tabular}

Comparing the proportions listed in Table 1 and those obtained by means of the SEM EDS method (cf. Table 2), it can be seen that the composition of the MP11 sample corresponds to a haematite/magnetite mixture with similar contents. In addition, slight amounts of aluminium and silicon were found in the sample. However, these contents are negligibly small in terms of the impact on erosive properties. A similar comparison made for the MP1-2 sample showed a slightly different composition corresponding to a magnetite/wustite mixture but with a higher content of magnetite (about $70 \%$ ). The result for the MP1-3 sample after elimination of $\mathrm{Al}$ and $\mathrm{Si}$ and conversion to contents of iron and oxygen only is the closest to haematite.

In summary, it may be stated that the oxide dust under analysis is a mixture of all three iron oxides and consists of larger contents of haematite and magnetite. From the perspective of erosion testing, such composition simulates well the material from austenitic superheaters exfoliated in the form of an epitactic layer. The layer is indeed mostly magnetite, but both the density (haematite: $4.9-5.3 \mathrm{~g} / \mathrm{cm}^{3}$, magnetite: 5.2 $\left.\mathrm{g} / \mathrm{cm}^{3}\right)$ and the hardness $(5.5-6.5$ in Mohs' scale) of the two oxides are similar.

\subsection{Adopted calculation methodology}

In graphical programs, the distance between individual points is given in pixels, which have to be converted to the real distance expressed in millimetres, covered by the erodent selected particles, to determine the real velocities of the particles in selected locations. The standard adopted for the conversion is a nozzle where the real distance between points $a$ and $b$ is $17 \mathrm{~mm}$ (Fig. 5).

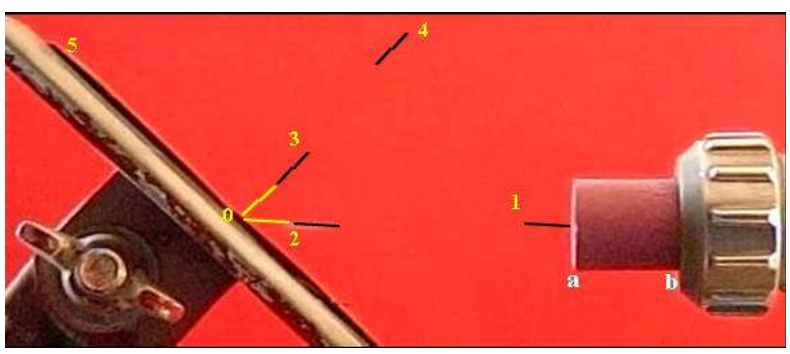

Fig. 5 Diagram of the test stand with marked characteristic points of the photographed particle trajectory. 
This distance has an equivalent value expressed in pixels. The correction conversion from [pixels] to [mm] was calculated using the following relation:

$$
v_{\text {pix }}=\frac{17}{a-b}=0.2982
$$

The equation describing the straight line passing through points $1\left(\mathrm{x}_{1}, \mathrm{y}_{1}\right), \mathbf{2}\left(\mathrm{x}_{2}, \mathrm{y}_{2}\right)$ takes the following form:

$$
\begin{aligned}
& y=m_{1} x+C_{1} \\
& m_{1}=\frac{y_{2}-y_{1}}{x_{2}-x_{1}} \quad C_{1}=y_{1}-m_{1} x_{1}
\end{aligned}
$$

The length of segment $d_{1}$ (the distance covered by the particle) between points 1 and 2 is:

$$
\begin{gathered}
d_{1}=\sqrt{\left(x_{2}-x_{1}\right)^{2}+\left(y_{2}-y_{1}\right)^{2}} \text { [pixels] } \\
d_{1}=v_{\text {pix }} d_{1} \quad[\mathrm{~mm}]
\end{gathered}
$$

If the time interval is known between subsequent frames of a film showing a particle ejected from the gun nozzle, it is possible to calculate the particle average velocity. The frame rate of the Casio High-Speed Exilim EX-F1 camera is $600 \mathrm{fps}$. This means that 1 frame moves in the time of $1 / 600=0.0016667 \mathrm{~s}$. Knowing the distance and the time it takes for the particle to traverse that distance, the average velocity $\left(w_{l}\right)$ at which the particle strikes against the plate mounted on the test stand may be calculated. Example subsequent phases of the erodent particles recorded with a specific time step are shown in Fig. 6.
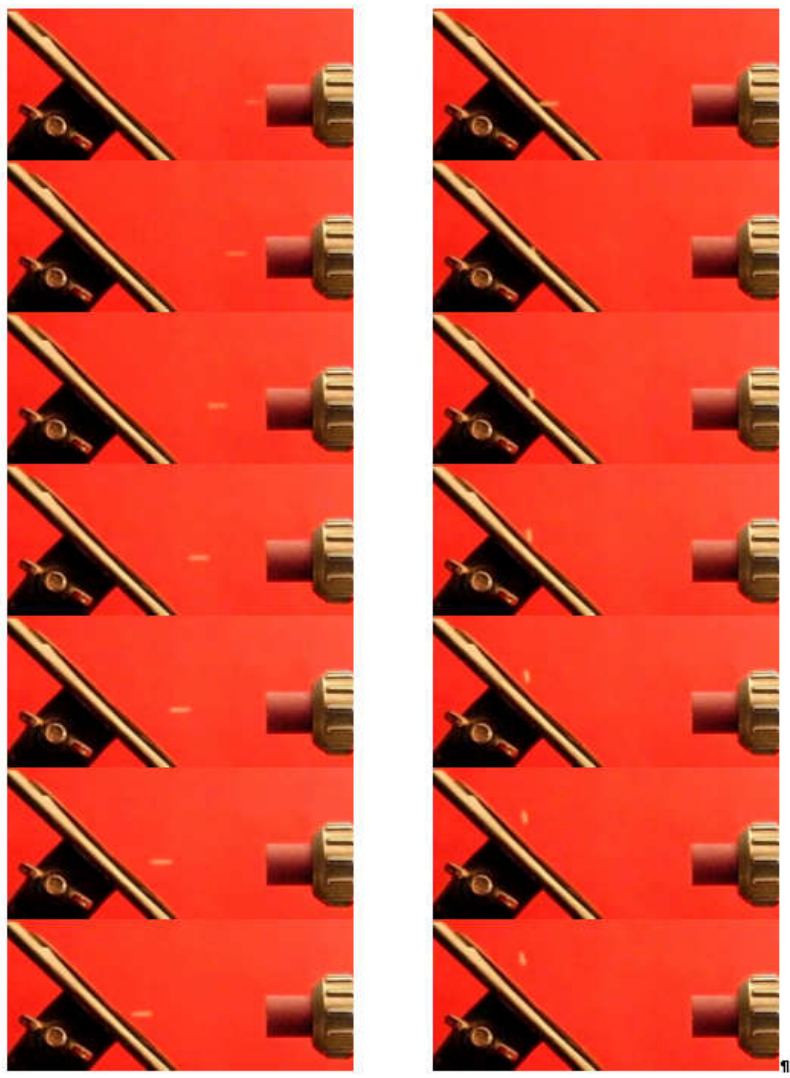

Fig. 6 Subsequent frames of a film showing the erodent motion before and after reflection off the plate.

$$
w_{1}=\frac{d_{1}}{1.6667 \tau_{1}} \quad[\mathrm{~m} / \mathrm{s}]
$$

where $\tau_{1}$ is the number of time steps for the particle ejected from the nozzle.
A similar procedure is followed to determine the equation describing the straight line passing through points $3\left(x_{3}, y_{3}\right), 4\left(x_{4}, y_{4}\right)$ related to the reflected particle.

$$
\begin{gathered}
y=m_{2} x+C_{2} \\
m_{2}=\frac{y_{4}-y_{3}}{x_{4}-x_{3}} \quad C_{2}=y_{3}-m_{2} x_{3} \\
w_{2}=\frac{d_{2}}{1.6667 \tau_{2}}
\end{gathered}
$$

Having two equations describing straight lines with slopes $m_{1} \neq m_{2}$, the intersection point of the lines is found by solving a system of equations. The intersection point is the point of the particle reflection off the analysed plate. If the lines intersect, the following condition must be satisfied:

$$
m_{1} x+C_{1}=m_{2} x+C_{2}
$$

which makes it possible to determine the reflection coordinate $x_{0}$ :

$$
x_{0}=\frac{C_{2}-C_{1}}{m_{1}-m_{2}}
$$

In the next step, using the equation describing the line passing through points 1 and 2 or 3 and 4 , the other coordinate $y_{0}$ is found. Coordinates $x_{0}, y_{0}$ relate to point 0 (reflection point - cf. Fig. 5).

In order to find the particle impingement and reflection angles, it is necessary to know the equation that describes the straight line lying on the plate. For this purpose, the coordinates are read of another point on the plate, e.g., $5\left(x_{5}, y_{5}\right)-$ Fig. 5 . The equation describing the straight line passing through points 0 and 5 has the following form:

$$
y=m_{3} x+C_{3}
$$

As a result, the particle impingement and reflection angles, $\alpha_{1}$ and $\alpha_{2}$, may be calculated from the following relations:

$$
\begin{gathered}
\operatorname{tg} \alpha_{1}=\left|\frac{m_{1}-m_{3}}{\left(1+m_{1} m_{3}\right.}\right| \\
\alpha_{1}=\operatorname{arc}\left(\operatorname{tg} \alpha_{1}\right) \frac{180}{\pi} \\
\operatorname{tg} \alpha_{2}=\left|\frac{m_{2}-m_{3}}{\left(1+m_{2} m_{3}\right.}\right| \\
\left.\alpha_{2}=\operatorname{arctg} \alpha_{2}\right) \frac{180}{\pi}
\end{gathered}
$$

Having the particle velocities and the impingement and reflection angles, restitution coefficients are calculated from the formulae (2 and 3 ).

\subsection{Experimental determination of restitution coefficients of erosion for a selected erodent}

The following erodents were used in the testing: iron oxides, quartz sand with a different grain size (490, $1000,1500,2000 \mu \mathrm{m})$, and $1000 \mu \mathrm{m}$-diameter steel balls. The steel balls, due to their ideal shape, were treated as the comparative analysis reference standard. In order to create an unequivocal state of reference, steel balls were used only for the steel plate impingement. 
Due to the possibility of finding certain differences resulting from the difference in the nature of the materials used in the testing, a combination of different erodents and plates was taken into consideration for the other cases.

Sifting the erodent through many sieves with different mesh sizes, a wide range of the grain size of the analysed iron oxides was obtained. The grain size ranges adopted for the testing of iron oxides were as follows:

- $500-600 \mu \mathrm{m}$, average value: $550 \mu \mathrm{m}$,

- $600-800 \mu \mathrm{m}$, average value: $700 \mu \mathrm{m}$,

- $1000-1180 \mu \mathrm{m}$, average value: $1090 \mu \mathrm{m}$,

- $1180-1500 \mu \mathrm{m}$, average value: $1340 \mu \mathrm{m}$,

- $1500-2000 \mu \mathrm{m}$, average value: $1750 \mu \mathrm{m}$,

- $2000-3000 \mu \mathrm{m}$, average value: $2500 \mu \mathrm{m}$.

Unlike the sand or steel balls, for which a spherical shape of particles is assumed in the CFD calculations, the particles of iron oxides, especially in the case of larger grains, have a highly irregular shape. The erodent very often has the shape of irregular flat flakes. The shape of the tested erodent was analysed by means of microscopic observations. For grain sizes higher than $1200 \mu \mathrm{m}$, the erodent was treated as an irregular particle; for sizes lower than $1200 \mu \mathrm{m}$, it was treated as a regular particle. After an analysis of many large particles of iron oxides (grain size higher than $1200 \mu \mathrm{m}$ ), it was assumed that the grain width and thickness were $50 \%$ and $20 \%$ of its length, respectively.

Based on that, for irregular grains bigger than 1200 $\mu \mathrm{m}$, the following was assumed:

- 1180-1500 $\mu \mathrm{m}$, length/width/thickness 1.34 / 0.67 /

$0.268 \mathrm{~mm}$

- 1500-2000 $\mu \mathrm{m}$, length/width/thickness 1.75 / 0.875 / $0.35 \mathrm{~mm}$,

- 2000-3000 $\mu \mathrm{m}$, length/width/thickness 2.5 / 1.25 / $0.5 \mathrm{~mm}$.

Restitution coefficients calculated according to formulae (1) and (2) for averaged variables affecting their values are listed in Table 5 - Table 17 together with a comparison to the CFD analysis results.

The results obtained during the test stand experiments show that the reflection angle $\alpha_{2}$ for sand particles is included in the range $(12-50)$. In the case of steel balls, the deviations are much smaller: $\alpha_{2}=(33-$ 42). For iron oxides, the reflection angle range is $\alpha_{2}=$ (17-29). The comparison indicates that the smallest deviations in the reflection angle value occur for the steel balls, which results from their regular shape.

\subsection{Numerical modelling of the erodent particle reflection off the surface}

Based on the restitution coefficient testing results, numerical simulations were performed of the particle reflection off the surface. The gaseous phase (air) and the solid phase (erodent) flows are modelled together.

The geometrical model and the numerical mesh are made in the CFD Ansys Fluent commercial software [9] (Fig. 7). The mesh is structural in the entire area, and a hexagonal mesh composed of 519,000 nodes is used.
For the calculation of trajectories of moving particles, the flow of the gaseous phase is modelled in the Euler coordinate system, whereas the flow of the moving particle is modelled in the Lagrangian coordinate system. The flow area is estimated using the SIMPLE method and the $k-\varepsilon$ real turbulence model. The interaction is used between the solid and the gaseous phase through the mass, energy, and momentum transfer. A spherical shape is assumed for the sand particles and the steel balls. For the iron oxides, a spherical shape of the erodent particles is assumed for three smaller diameters and a non-spherical shape is assumed for three bigger diameters.

The calculations were performed for averaged values of quantities obtained on the test stand for the erodent selected diameters and for three kinds of eroded materials. The CFD model boundary conditions are listed in Table 3 and Table 4.

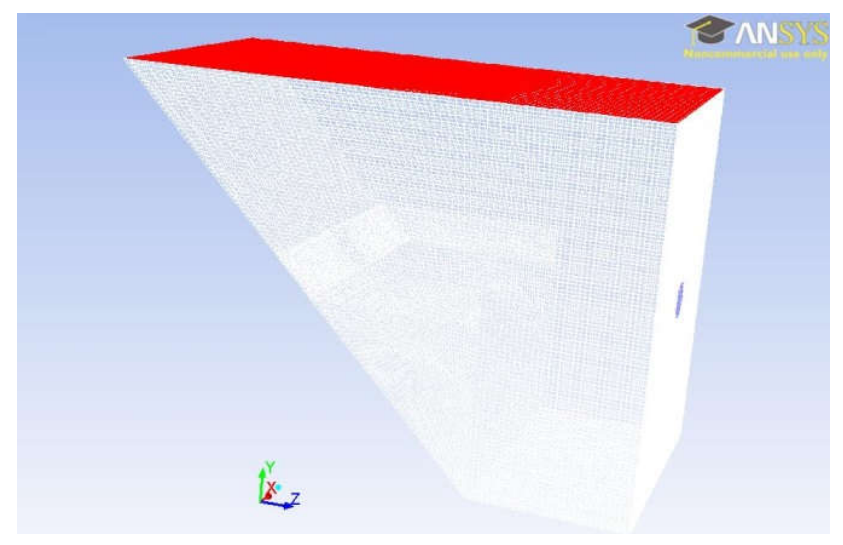

Fig. 7 Model contour.

Table 3. CFD model boundary conditions for steel, aluminium, and steel with an anti-erosion coating; erodent: iron oxides.

\begin{tabular}{|c|c|c|c|c|c|c|}
\hline $\begin{array}{l}\text { Particle average } \\
\text { diameter [mm] }\end{array}$ & 0.55 & 0.70 & 1.09 & 1.34 & 1.75 & 2.5 \\
\hline Eroded material & \multicolumn{6}{|c|}{ Steel } \\
\hline $\begin{array}{l}\text { Impingement velocity } \\
w_{1}[\mathrm{~m} / \mathrm{s}]\end{array}$ & 6.20 & 5.76 & 5.18 & 4.34 & 4.41 & 3.77 \\
\hline $\begin{array}{c}\text { Restitution coefficient } \\
e_{n}\end{array}$ & 0.26 & 0.32 & 0.38 & 0.36 & 0.33 & 0.23 \\
\hline $\begin{array}{c}\text { Restitution coefficient } \\
e_{t}\end{array}$ & 0.59 & 0.59 & 0.62 & 0.58 & 0.63 & 0.66 \\
\hline Eroded material & \multicolumn{6}{|c|}{ Aluminium } \\
\hline $\begin{array}{c}\text { Impingement velocity } \\
w_{1}[\mathrm{~m} / \mathrm{s}]\end{array}$ & 7.33 & 6.28 & 4.04 & 4.95 & 3.86 & 4.00 \\
\hline $\begin{array}{c}\text { Restitution coefficient } \\
e_{n}\end{array}$ & 0.30 & 0.34 & 0.39 & 0.32 & 0.27 & 0.26 \\
\hline $\begin{array}{c}\text { Restitution coefficient } \\
e_{t} \\
\end{array}$ & 0.67 & 0.69 & 0.71 & 0.66 & 0.62 & 0.59 \\
\hline Eroded material & \multicolumn{6}{|c|}{ Plate with an anti-erosion coating } \\
\hline $\begin{array}{c}\text { Impingement velocity } \\
w_{1}[\mathrm{~m} / \mathrm{s}]\end{array}$ & 5.83 & 5.89 & 4.65 & 5.76 & 4.26 & 3.75 \\
\hline $\begin{array}{c}\text { Restitution coefficient } \\
e_{n}\end{array}$ & 0.34 & 0.30 & 0.38 & 0.24 & 0.33 & 0.33 \\
\hline $\begin{array}{l}\text { Restitution coefficient } \\
e_{t}\end{array}$ & 0.59 & 0.54 & 0.63 & 0.60 & 0.53 & 0.54 \\
\hline
\end{tabular}


Table 4. CFD model boundary conditions for steel, aluminium, and steel with an anti-erosion coating; erodent: sand, steel balls.

\begin{tabular}{|c|c|c|c|c|c|}
\hline Erodent & \multicolumn{4}{|c|}{ Sand } & \multirow{2}{*}{$\begin{array}{l}\begin{array}{l}\text { Steel } \\
\text { balls }\end{array} \\
1.00\end{array}$} \\
\hline $\begin{array}{l}\text { Particle average } \\
\text { diameter }[\mathrm{mm}]\end{array}$ & 0.49 & 0.10 & 1.50 & 2.00 & \\
\hline Eroded material & \multicolumn{5}{|c|}{ Steel } \\
\hline $\begin{array}{l}\text { Impingement velocity } \\
\qquad w_{1}[\mathrm{~m} / \mathrm{s}]\end{array}$ & 6.37 & 5.85 & 8.76 & 9.53 & 8.72 \\
\hline $\begin{array}{c}\text { Restitution coefficient } \\
e_{n} \\
\end{array}$ & 0.46 & 0.46 & 0.63 & 0.41 & 0.55 \\
\hline $\begin{array}{c}\text { Restitution coefficient } \\
e_{t}\end{array}$ & 0.73 & 0.72 & 0.76 & 0.69 & 0.71 \\
\hline Eroded material & \multicolumn{5}{|c|}{ Aluminium } \\
\hline $\begin{array}{l}\text { Impingement velocity } \\
\qquad w_{1}[\mathrm{~m} / \mathrm{s}]\end{array}$ & 6.15 & 5.73 & 6.98 & 6.17 & - \\
\hline $\begin{array}{c}\text { Restitution coefficient } \\
e_{n}\end{array}$ & 0.40 & 0.33 & 0.37 & 0.41 & - \\
\hline $\begin{array}{c}\text { Restitution coefficient } \\
e_{t}\end{array}$ & 0.81 & 0.77 & 0.73 & 0.71 & - \\
\hline Eroded material & \multicolumn{5}{|c|}{$\begin{array}{l}\text { Plate with an anti-erosion } \\
\text { coating }\end{array}$} \\
\hline $\begin{array}{l}\text { Impingement velocity } \\
\qquad w_{1}[\mathrm{~m} / \mathrm{s}]\end{array}$ & 7.54 & 6.53 & 7.70 & 5.85 & - \\
\hline $\begin{array}{l}\text { Restitution coefficient } \\
e_{n}\end{array}$ & 0.38 & 0.54 & 0.50 & 0.70 & - \\
\hline $\begin{array}{c}\text { Restitution coefficient } \\
e_{t}\end{array}$ & 0.76 & 0.73 & 0.58 & 0.59 & - \\
\hline
\end{tabular}

The figures below present results of numerical calculations performed to determine the restitution coefficient (both tangential and normal) for different erodents. Fig. 8 and Fig. 9 presents an example trajectory of the erodent (iron oxide) particle, which is shown as the velocity before and after impingement on the eroded surface for steel and 6 diameters of the erodent. On the Fig. 8 in the top (T), the trajectory is shown for the 0.55 $\mathrm{mm}$ diameter. In the middle $(\mathrm{M})$, the trajectory is shown for the diameter of $0.7 \mathrm{~mm}$. In the bottom (B), the trajectory is shown for the diameter of $1.09 \mathrm{~mm}$. On the Fig. 9 in the top (T), it is shown for the $1.34 \mathrm{~mm}$ diameter. In the middle (M)r, the trajectory is shown for the $1.75 \mathrm{~mm}$ diameter and in the bottom (B), it is shown for the diameter of $2.5 \mathrm{~mm}$.

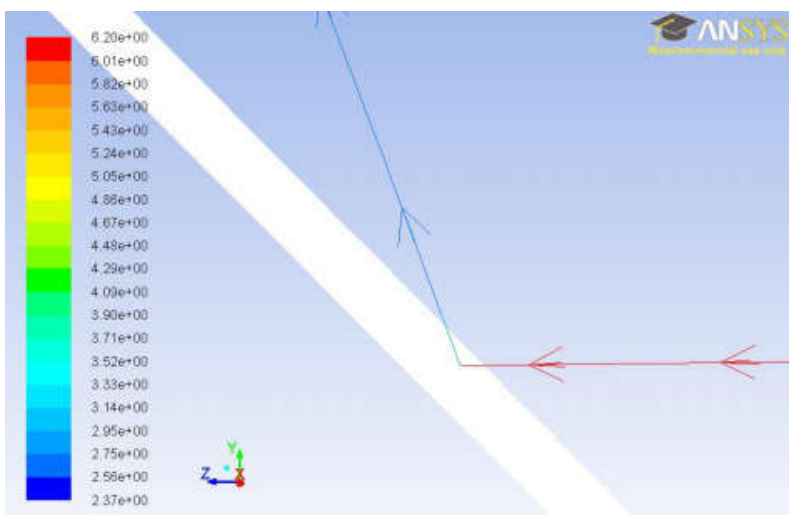

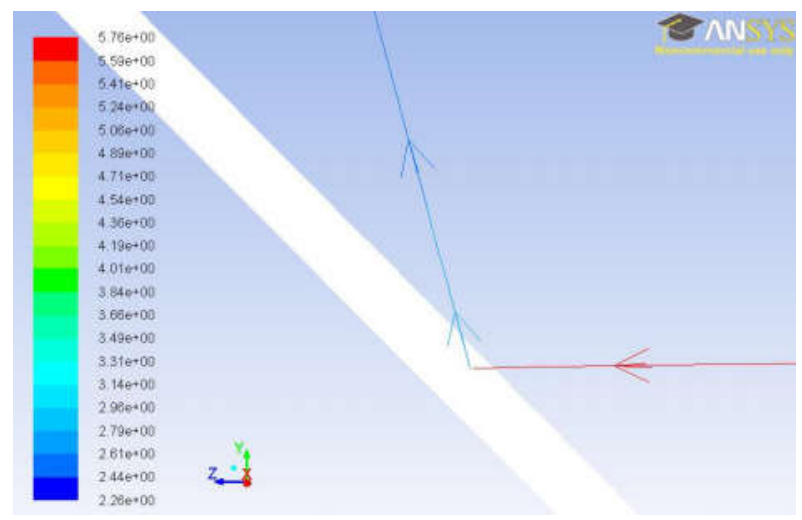

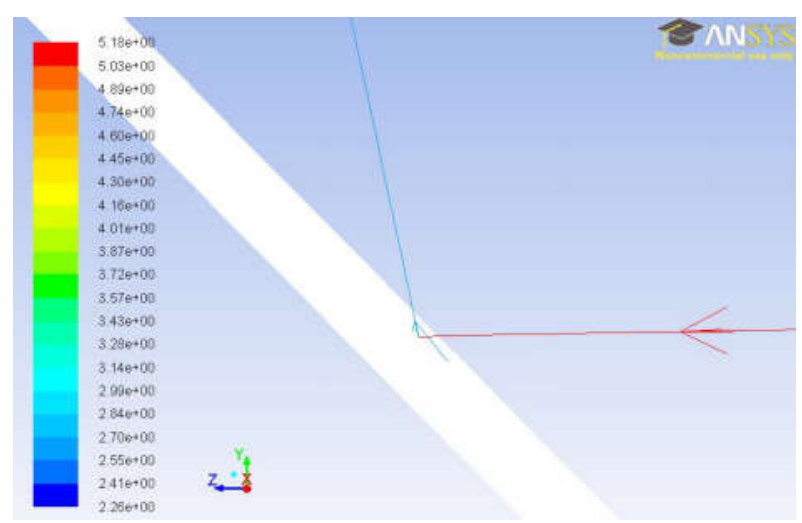

Fig. 8 Trajectory of the erodent (iron oxide) particle shown as the velocity before and after impingement on the eroded surface for steel and 6 diameters of the erodent: $0.55(\mathrm{~T}), 0.7$ (M), 1.09 (B).
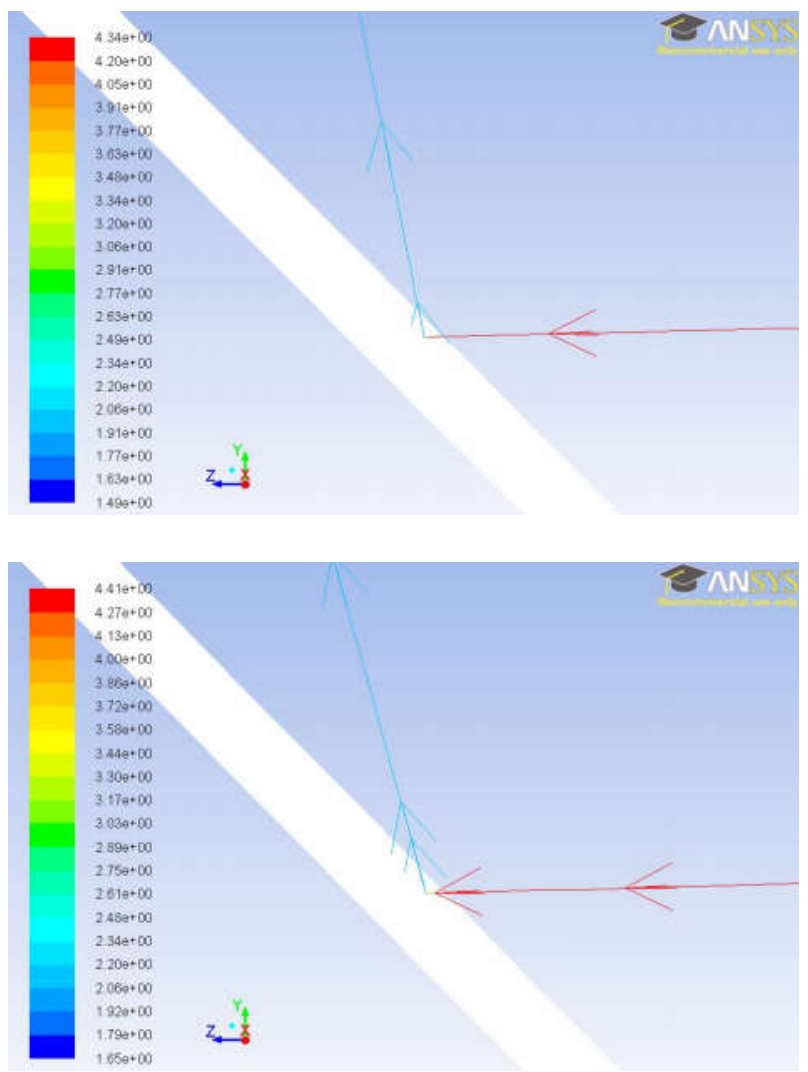


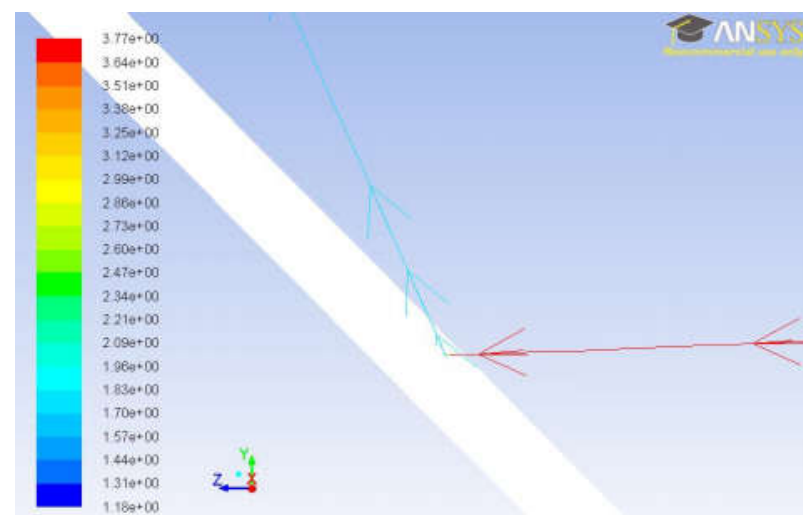

Fig. 9 Trajectory of the erodent (iron oxide) particle shown as the velocity before and after impingement on the eroded surface for steel and 6 diameters of the erodent: 1.34 (T), 1.75 (M), 2.5 (B).

Table 5-Table 17 present the numerical modelling results together with the assumed values obtained from the test stand experiments for selected diameters of the erodent (iron oxide, sand, steel balls) and for three analysed samples (steel plate, aluminium plate, and plate with an anti-erosion coating).

Table 5. List of results obtained from laboratory testing for steel - erodent: iron oxide.

\begin{tabular}{|c|c|c|c|c|c|c|}
\hline $\begin{array}{c}\text { Erodent } \\
\text { Iron oxide }\end{array}$ & \multicolumn{5}{|c|}{ EXPERIMENTS } \\
\hline $\begin{array}{c}\text { Particle } \\
\text { diameter [mm] }\end{array}$ & 0.55 & 0.70 & 1.09 & 1.34 & 1.75 & 2.5 \\
\hline $\begin{array}{c}\text { Impingement } \\
\text { velocity } \boldsymbol{w}_{\boldsymbol{1}}[\mathbf{m} / \mathbf{s} \text { ] }\end{array}$ & 6.20 & 5.76 & 5.18 & 4.34 & 4.41 & 3.77 \\
\hline $\begin{array}{c}\text { Reflection } \\
\text { velocity } \boldsymbol{w}_{\boldsymbol{2}}[\mathbf{m} / \mathbf{s} \text { ] }\end{array}$ & 2.95 & 2.81 & 2.73 & 2.15 & 2.31 & 1.95 \\
\hline $\begin{array}{c}\text { Impingement } \\
\text { angle } \boldsymbol{I}\end{array}$ & 41.88 & 41.30 & 41.19 & 41.54 & 40.96 & 41.63 \\
\hline $\begin{array}{c}\text { Reflection angle } \\
\boldsymbol{2}\end{array}$ & 21.73 & 25.60 & 27.98 & 28.79 & 24.55 & 17.31 \\
\hline $\begin{array}{c}\text { Restitution } \\
\text { coefficient } \boldsymbol{e}_{\boldsymbol{n}}\end{array}$ & 0.26 & 0.32 & 0.38 & 0.36 & 0.33 & 0.23 \\
\hline $\begin{array}{c}\text { Restitution } \\
\text { coefficient } \boldsymbol{e}_{\boldsymbol{t}}\end{array}$ & 0.59 & 0.59 & 0.62 & 0.58 & 0.63 & 0.66 \\
\hline
\end{tabular}

Table 6. List of results obtained from CFD simulations for steel - erodent: iron oxide.

\begin{tabular}{|l|c|c|c|c|c|c|}
\hline $\begin{array}{l}\text { Erodent } \\
\text { Iron oxide }\end{array}$ & \multicolumn{6}{|c|}{ CFD } \\
\hline $\begin{array}{l}\text { Particle diameter } \\
\text { [mm] }\end{array}$ & 0.55 & 0.70 & 1.09 & 1.34 & 1.75 & 2.5 \\
\hline $\begin{array}{l}\text { Impingement } \\
\text { velocity } \boldsymbol{w}_{\boldsymbol{1}}[\mathbf{m} / \mathbf{s}]\end{array}$ & 6.14 & 5.71 & 5.15 & 4.27 & 4.34 & 3.71 \\
\hline $\begin{array}{l}\text { Reflection } \\
\text { velocity } \boldsymbol{w}_{\boldsymbol{2}}[\mathbf{m} / \mathbf{s}]\end{array}$ & 2.76 & 2.65 & 2.62 & 2.03 & 2.14 & 1.76 \\
\hline $\begin{array}{l}\text { Impingement } \\
\text { angle } \boldsymbol{\alpha}_{\boldsymbol{1}}\end{array}$ & 45 & 45 & 45 & 45 & 45 & 45 \\
\hline $\begin{array}{l}\text { Reflection angle } \\
\boldsymbol{\alpha}_{2}\end{array}$ & 23.9 & 29 & 31 & 32 & 28 & 20 \\
\hline $\begin{array}{l}\text { Restitution } \\
\text { coefficient } \boldsymbol{e}_{\boldsymbol{n}}\end{array}$ & 0.26 & 0.32 & 0.37 & 0.36 & 0.33 & 0.23 \\
\hline $\begin{array}{l}\text { Restitution } \\
\text { coefficient } \boldsymbol{e}_{\boldsymbol{t}}\end{array}$ & 0.58 & 0.57 & 0.62 & 0.57 & 0.62 & 0.63 \\
\hline
\end{tabular}

Table 7. List of results obtained from laboratory testing for aluminium - erodent: iron oxide

\begin{tabular}{|c|c|c|c|c|c|c|}
\hline $\begin{array}{c}\text { Erodent } \\
\text { Iron oxide }\end{array}$ & \multicolumn{6}{|c|}{ EXPERIMENTS } \\
\hline $\begin{array}{c}\text { Particle } \\
\text { diameter [mm] }\end{array}$ & 0.55 & 0.70 & 1.09 & 1.34 & 1.75 & 2.5 \\
\hline $\begin{array}{c}\text { Impingement } \\
\text { velocity } \boldsymbol{w}_{\boldsymbol{1}}[\mathbf{m} / \mathbf{s} \text { ] }\end{array}$ & 7.33 & 6.28 & 4.04 & 4.95 & 3.86 & 4.00 \\
\hline $\begin{array}{c}\text { Reflection } \\
\text { velocity } \boldsymbol{w}_{\boldsymbol{2}}[\mathbf{m} / \mathbf{s} \text { ] }\end{array}$ & 3.86 & 3.44 & 2.33 & 2.61 & 1.92 & 1.87 \\
\hline $\begin{array}{c}\text { Impingement } \\
\text { angle } \boldsymbol{\alpha}_{\boldsymbol{1}}\end{array}$ & 44.14 & 44.26 & 43.98 & 43.51 & 41.76 & 42.94 \\
\hline $\begin{array}{c}\text { Reflection angle } \\
\boldsymbol{\alpha}_{\boldsymbol{2}}\end{array}$ & 23.64 & 26.05 & 28.18 & 24.40 & 21.31 & 22.45 \\
\hline $\begin{array}{c}\text { Restitution } \\
\text { coefficient } \boldsymbol{e}_{\boldsymbol{n}}\end{array}$ & 0.30 & 0.34 & 0.39 & 0.32 & 0.27 & 0.26 \\
\hline $\begin{array}{c}\text { Restitution } \\
\text { coefficient } \boldsymbol{e}_{\boldsymbol{t}}\end{array}$ & 0.67 & 0.69 & 0.71 & 0.66 & 0.62 & 0.59 \\
\hline
\end{tabular}

Table 8. List of results obtained from CFD simulations for aluminium - erodent: iron oxide

\begin{tabular}{|l|c|c|c|c|c|c|}
\hline $\begin{array}{l}\text { Erodent } \\
\text { Iron oxide }\end{array}$ & \multicolumn{5}{|c|}{ CFD } \\
\hline $\begin{array}{l}\text { Particle diameter } \\
\text { [mm] }\end{array}$ & 0.55 & 0.70 & 1.09 & 1.34 & 1.75 & 2.5 \\
\hline $\begin{array}{l}\text { Impingement } \\
\text { velocity } \boldsymbol{w}_{\boldsymbol{1}}[\mathbf{m} / \mathbf{s}]\end{array}$ & 7.25 & 6.21 & 4.01 & 4.84 & 3.76 & 3.93 \\
\hline $\begin{array}{l}\text { Reflection } \\
\text { velocity } \boldsymbol{w}_{\boldsymbol{2}}[\mathbf{m} / \mathbf{s}]\end{array}$ & 3.73 & 3.34 & 2.29 & 2.5 & 1.79 & 1.79 \\
\hline $\begin{array}{l}\text { Impingement } \\
\text { angle } \boldsymbol{\alpha}_{\boldsymbol{1}}\end{array}$ & 45 & 45 & 45 & 45 & 45 & 45 \\
\hline $\begin{array}{l}\text { Reflection angle } \\
\boldsymbol{\alpha}_{\boldsymbol{2}}\end{array}$ & 24.9 & 26.92 & 29.0 & 26.36 & 23.31 & 22.77 \\
\hline $\begin{array}{l}\text { Restitution } \\
\text { coefficient } \boldsymbol{e}_{\boldsymbol{n}}\end{array}$ & 0.31 & 0.34 & 0.39 & 0.32 & 0.27 & 0.25 \\
\hline $\begin{array}{l}\text { Restitution } \\
\text { coefficient } \boldsymbol{e}_{\boldsymbol{t}}\end{array}$ & 0.66 & 0.68 & 0.71 & 0.65 & 0.62 & 0.59 \\
\hline
\end{tabular}

Table 9. List of results obtained from laboratory testing for the plasma-coated plate with an anti-erosion layer - erodent: iron oxide

\begin{tabular}{|c|c|c|c|c|c|c|}
\hline $\begin{array}{c}\text { Erodent } \\
\text { Iron oxide }\end{array}$ & \multicolumn{7}{|c|}{ EXPERIMENTS } \\
\hline $\begin{array}{c}\text { Particle diameter } \\
\text { [mm] }\end{array}$ & 0.55 & 0.70 & 1.09 & 1.34 & 1.75 & 2.5 \\
\hline $\begin{array}{c}\text { Impingement } \\
\text { velocity } \boldsymbol{w}_{\boldsymbol{1}}[\mathbf{m} / \mathbf{s}]\end{array}$ & 5.83 & 5.89 & 4.65 & 5.76 & 4.26 & 3.75 \\
\hline $\begin{array}{c}\text { Reflection } \\
\text { velocity } \boldsymbol{w}_{2} \text { [m/s] }\end{array}$ & 2.92 & 2.69 & 2.50 & 2.76 & 1.94 & 1.72 \\
\hline $\begin{array}{c}\text { Impingement } \\
\text { angle } \boldsymbol{\alpha}_{\boldsymbol{I}}\end{array}$ & 39.83 & 39.75 & 39.97 & 41.61 & 41.42 & 41.02 \\
\hline $\begin{array}{c}\text { Reflection angle } \\
\boldsymbol{\alpha}_{2}\end{array}$ & 25.95 & 25.12 & 26.78 & 19.57 & 28.65 & 27.94 \\
\hline $\begin{array}{c}\text { Restitution } \\
\text { coefficient } \boldsymbol{e}_{\boldsymbol{n}}\end{array}$ & 0.34 & 0.30 & 0.38 & 0.24 & 0.33 & 0.33 \\
\hline $\begin{array}{c}\text { Restitution } \\
\text { coefficient } \boldsymbol{e}_{\boldsymbol{t}}\end{array}$ & 0.59 & 0.54 & 0.63 & 0.60 & 0.53 & 0.54 \\
\hline
\end{tabular}


Table 10. List of results obtained from CFD simulations for the plasma-coated plate with an anti-erosion layer - erodent: iron oxide

\begin{tabular}{|l|c|c|c|c|c|c|}
\hline $\begin{array}{l}\text { Erodent } \\
\text { Iron oxide }\end{array}$ & \multicolumn{5}{|c|}{ CFD } \\
\hline $\begin{array}{l}\text { Particle diameter } \\
\text { [mm] }\end{array}$ & 0.55 & 0.70 & 1.09 & 1.34 & 1.75 & 2.5 \\
\hline $\begin{array}{l}\text { Impingement } \\
\text { velocity } \boldsymbol{w}_{\boldsymbol{1}}[\mathrm{m} / \mathbf{s}]\end{array}$ & 5.74 & 5.82 & 4.62 & 5.66 & 4.16 & 3.67 \\
\hline $\begin{array}{l}\text { Reflection } \\
\text { velocity } \boldsymbol{w}_{2}[\mathrm{~m} / \mathbf{s}]\end{array}$ & 2.76 & 2.54 & 2.4 & 2.58 & 1.84 & 1.64 \\
\hline $\begin{array}{l}\text { Impingement } \\
\text { angle } \boldsymbol{\alpha}_{\boldsymbol{I}}\end{array}$ & 45 & 45 & 45 & 45 & 45 & 45 \\
\hline $\begin{array}{l}\text { Reflection angle } \\
\boldsymbol{\alpha}_{2}\end{array}$ & 29.65 & 29.15 & 31.14 & 22.19 & 31.35 & 31.17 \\
\hline $\begin{array}{l}\text { Restitution } \\
\text { coefficient } \boldsymbol{e}_{\boldsymbol{n}}\end{array}$ & 0.34 & 0.30 & 0.38 & 0.24 & 0.33 & 0.33 \\
\hline $\begin{array}{l}\text { Restitution } \\
\text { coefficient } \boldsymbol{e}_{\boldsymbol{t}}\end{array}$ & 0.59 & 0.54 & 0.63 & 0.60 & 0.53 & 0.54 \\
\hline
\end{tabular}

Table 11. List of results obtained from laboratory testing for steel erosion - erodent: sand

\begin{tabular}{|c|c|c|c|c|}
\hline $\begin{array}{c}\text { Erodent } \\
\text { Sand }\end{array}$ & \multicolumn{4}{|c|}{ EXPERIMENTS } \\
\hline Particle diameter $[\mathbf{m m}]$ & 0.49 & 1.00 & 1.50 & 2.00 \\
\hline $\begin{array}{c}\text { Impingement velocity } \boldsymbol{w}_{\boldsymbol{1}} \\
{[\mathbf{m} / \mathbf{s}]}\end{array}$ & 6.37 & 5.85 & 8.76 & 9.54 \\
\hline Reflection velocity $\boldsymbol{w}_{\boldsymbol{2}}[\mathbf{m} / \mathbf{s}]$ & 3.93 & 3.53 & 6.20 & 5.41 \\
\hline Impingement angle $\boldsymbol{\alpha}_{\boldsymbol{1}}$ & 43.16 & 44.58 & 40.79 & 44.34 \\
\hline Reflection angle $\boldsymbol{\alpha}_{\boldsymbol{2}}$ & 30.87 & 32.37 & 35.87 & 29.94 \\
\hline Restitution coefficient $\boldsymbol{e}_{\boldsymbol{n}}$ & 0.46 & 0.46 & 0.63 & 0.41 \\
\hline Restitution coefficient $\boldsymbol{e}_{\boldsymbol{t}}$ & 0.73 & 0.72 & 0.76 & 0.67 \\
\hline
\end{tabular}

Table 12. List of results obtained from CFD simulations for steel erosion - erodent: sand

\begin{tabular}{|c|c|c|c|c|}
\hline $\begin{array}{c}\text { Erodent } \\
\text { Sand }\end{array}$ & \multicolumn{4}{|c|}{ CFD } \\
\hline Particle diameter $[\mathbf{m m}]$ & 0.49 & 1.00 & 1.50 & 2.00 \\
\hline $\begin{array}{c}\text { Impingement velocity } \boldsymbol{w}_{\boldsymbol{1}} \\
{[\mathbf{m} / \mathbf{s}]}\end{array}$ & 6.22 & 5.8 & 8.74 & 9.52 \\
\hline Reflection velocity $\boldsymbol{w}_{\boldsymbol{2}}[\mathbf{m} / \mathbf{s}]$ & 3.8 & 3.5 & 6.1 & 5.4 \\
\hline Impingement angle $\boldsymbol{\alpha}_{\boldsymbol{1}}$ & 45 & 45 & 45 & 45 \\
\hline Reflection angle $\boldsymbol{\alpha}_{\boldsymbol{2}}$ & 32 & 33 & 39 & 30 \\
\hline Restitution coefficient $\boldsymbol{e}_{\boldsymbol{n}}$ & 0.46 & 0.46 & 0.62 & 0.40 \\
\hline Restitution coefficient $\boldsymbol{e}_{\boldsymbol{t}}$ & 0.73 & 0.72 & 0.77 & 0.69 \\
\hline
\end{tabular}

Table 13. List of results obtained from laboratory testing for aluminium erosion - erodent: sand

\begin{tabular}{|c|c|c|c|c|}
\hline $\begin{array}{c}\text { Erodent } \\
\text { Sand }\end{array}$ & \multicolumn{4}{|c|}{ EXPERIMENTS } \\
\hline Particle diameter $[\mathbf{m m}]$ & 0.49 & 1.00 & 1.50 & 2.00 \\
\hline $\begin{array}{c}\text { Impingement velocity } \boldsymbol{w}_{\boldsymbol{1}} \\
{[\mathbf{m} / \mathbf{s}]}\end{array}$ & 6.15 & 5.73 & 6.98 & 6.17 \\
\hline Reflection velocity $\boldsymbol{w}_{\boldsymbol{2}}[\mathbf{m} / \mathbf{s}]$ & 3.92 & 3.38 & 4.04 & 3.64 \\
\hline Impingement angle $\boldsymbol{\alpha}_{\boldsymbol{1}}$ & 44.81 & 45.32 & 44.56 & 43.84 \\
\hline Reflection angle $\boldsymbol{\alpha}_{\boldsymbol{2}}$ & 25.99 & 23.37 & 26.74 & 28.93 \\
\hline Restitution coefficient $\boldsymbol{e}_{\boldsymbol{n}}$ & 0.39 & 0.33 & 0.37 & 0.41 \\
\hline Restitution coefficient $\boldsymbol{e}_{\boldsymbol{t}}$ & 0.80 & 0.78 & 0.72 & 0.71 \\
\hline
\end{tabular}

Table 14. List of results obtained from CFD simulations for aluminium erosion - erodent: sand

\begin{tabular}{|c|c|c|c|c|}
\hline $\begin{array}{c}\text { Erodent } \\
\text { Sand }\end{array}$ & \multicolumn{4}{|c|}{ CFD } \\
\hline Particle diameter $[\mathbf{m m}]$ & 0.49 & 1.00 & 1.50 & 2.00 \\
\hline $\begin{array}{c}\text { Impingement velocity } \boldsymbol{w}_{\boldsymbol{1}} \\
{[\mathbf{m} / \mathbf{s}]}\end{array}$ & 6.02 & 5.68 & 6.95 & 6.15 \\
\hline Reflection velocity $\boldsymbol{w}_{\boldsymbol{2}}[\mathbf{m} / \mathbf{s}]$ & 3.85 & 3.37 & 4.02 & 3.56 \\
\hline Impingement angle $\boldsymbol{\alpha}_{\boldsymbol{1}}$ & 45 & 45 & 45 & 45 \\
\hline Reflection angle $\boldsymbol{\alpha}_{\boldsymbol{2}}$ & 26 & 23 & 27 & 30 \\
\hline Restitution coefficient $\boldsymbol{e}_{\boldsymbol{n}}$ & 0.40 & 0.33 & 0.37 & 0.41 \\
\hline Restitution coefficient $\boldsymbol{e}_{\boldsymbol{t}}$ & 0.81 & 0.77 & 0.73 & 0.71 \\
\hline
\end{tabular}

Table 15. List of results obtained from laboratory testing for erosion of the plasma-coated plate with an anti-erosion layererodent: sand

\begin{tabular}{|c|c|c|c|c|}
\hline $\begin{array}{c}\text { Erodent } \\
\text { Sand }\end{array}$ & \multicolumn{4}{|c|}{ EXPERIMENTS } \\
\hline Particle diameter $[\mathbf{m m}]$ & 0.49 & 1.00 & 1.50 & 2.00 \\
\hline $\begin{array}{c}\text { Impingement velocity } \boldsymbol{w}_{\boldsymbol{1}} \\
{[\mathbf{m} / \mathbf{s}]}\end{array}$ & 7.54 & 6.53 & 7.70 & 5.58 \\
\hline Reflection velocity $\boldsymbol{w}_{\boldsymbol{2}}[\mathbf{m} / \mathbf{s}]$ & 4.60 & 4.26 & 4.22 & 3.76 \\
\hline Impingement angle $\boldsymbol{\alpha}_{\boldsymbol{1}}$ & 43.40 & 42.08 & 42.63 & 43.42 \\
\hline Reflection angle $\boldsymbol{\alpha}_{\boldsymbol{2}}$ & 25.33 & 33.47 & 38.49 & 48.54 \\
\hline Restitution coefficient $\boldsymbol{e}_{\boldsymbol{n}}$ & 0.38 & 0.52 & 0.46 & 0.70 \\
\hline Restitution coefficient $\boldsymbol{e}_{\boldsymbol{t}}$ & 0.76 & 0.72 & 0.57 & 0.59 \\
\hline
\end{tabular}

Table 16. List of results obtained from CFD simulations for erosion of the plasma-coated plate with an anti-erosion layererodent: sand

\begin{tabular}{|c|c|c|c|c|}
\hline $\begin{array}{c}\text { Erodent } \\
\text { Sand }\end{array}$ & \multicolumn{4}{|c|}{ CFD } \\
\hline Particle diameter $[\mathbf{m m}]$ & 0.49 & 1.00 & 1.50 & 2.00 \\
\hline $\begin{array}{c}\text { Impingement velocity } \boldsymbol{w}_{\boldsymbol{1}} \\
{[\mathbf{m} / \mathbf{s}]}\end{array}$ & 7.45 & 6.48 & 7.66 & 5.83 \\
\hline Reflection velocity $\boldsymbol{w}_{\boldsymbol{2}}[\mathbf{m} / \mathbf{s}]$ & 4.47 & 4.16 & 4.15 & 3.77 \\
\hline Impingement angle $\boldsymbol{\alpha}_{\boldsymbol{1}}$ & 45 & 45 & 45 & 45 \\
\hline Reflection angle $\boldsymbol{\alpha}_{\boldsymbol{2}}$ & 27 & 36 & 41 & 49 \\
\hline Restitution coefficient $\boldsymbol{e}_{\boldsymbol{n}}$ & 0.39 & 0.53 & 0.50 & 0.69 \\
\hline Restitution coefficient $\boldsymbol{e}_{\boldsymbol{t}}$ & 0.76 & 0.73 & 0.58 & 0.60 \\
\hline
\end{tabular}

Table 17. List of results obtained from laboratory testing and CFD simulations for steel erosion; erodent: steel balls

\begin{tabular}{|l|c|c|}
\hline Erodent - Steel balls & EXPERIMENTS & CFD \\
\hline Particle diameter $[\mathrm{mm}]$ & 1.0 & 1.0 \\
\hline Impingement velocity $w_{1}[\mathrm{~m} / \mathrm{s}]$ & 8.72 & 8.72 \\
\hline Reflection velocity $w_{2}[\mathrm{~m} / \mathrm{s}]$ & 5.54 & 5.52 \\
\hline Impingement angle $\alpha_{1}$ & 43.89 & 45 \\
\hline Reflection angle $\alpha_{2}$ & 36.74 & 37.43 \\
\hline Restitution coefficient $e_{n}$ & 0.55 & 0.54 \\
\hline Restitution coefficient $e_{t}$ & 0.71 & 0.71 \\
\hline
\end{tabular}

Attention should be drawn to slight discrepancies between the values of the impingement and reflection angles $\alpha_{1}$ and $\alpha_{2}$, respectively, obtained from experiments and from the CFD numerical model (Table 5 - Table 17). Assuming that restitution coefficients on 
the plate wall in the CFD analysis are identical to coefficients according to the experiments, a similar difference between the impingement/reflection angles is obtained from numerical and experimental investigations. If, however, the numerical model impingement angle is changed from $\alpha_{1}=45^{\circ}$ (the angle of the plate inclination on the test stand) to the angle used in the analysis, a different reflection angle is obtained but the CFD restitution coefficients remain unchanged.

The angle of $45^{\circ}$ is assumed as a typical value for which the maximum erosion loss occurs for steel.

\section{Summary and conclusions}

- In case of two-phase gas-solid flows the rate of erosion and the restitution coefficients depend on the concentration of solid phase in the flow. During experimental determination of restitution coefficients it is impossible to keep the initial parameters (impingement velocity $w_{1}$ and angle $\alpha_{1}$ ) at a steady level. Therefore, the physical experiments don't bring full information about dependence of $e_{t}$ and $e_{n}$ on parameters influencing the phenomenon of particle reflection off the eroded surface. In this situation it was necessary to create the numerical model enabling correction of process conditions in such a way that the influence of particular parameters is identifiable.

- Comparing Tables 5 - 17, it can be seen that good accordance is obtained between the results of numerical modelling and experimental testing, which proves the correctness of the numerical model of the restitution coefficient determination. This means that numerical modelling may be a useful tool for multivariant analyses of the particle reflection off the surface.

- Based on the value of the restitution coefficient tangential component $e_{t}$, it is found that regardless of the erodent particle size or the erodent type, the biggest values of $e_{t}$ occurred for the aluminium plate erosion. The lowest values of $e_{t}$ occurred for the plasma-coated plate.

- Analysing the results listed in the tables presented above (Table 11 - 16), a distinct impact of the tested material plastic deformation can be observed. For example, if the impingement of sand particles with the diameter of $1.0 \mathrm{~mm}$ on various types of the eroded material is investigated, it may be stated that by steady impingement angle $\alpha_{1}$ the lowest reflection angle $\alpha_{2}$ occurs in the case of the aluminium plate (the the most ductile material), while the highest for the plasma-coated plate (the most brittle material). The mean value occurs by reflection of sand from the steel.

- Regardless of the size of particles and the type of erodent the highest values of $e_{t}$ are for the aluminium plate

$$
\begin{aligned}
& \text { - sand/aluminium } \\
& \text { - sand/steel }
\end{aligned}
$$

$$
\begin{aligned}
& e_{t}=0,71 \div 0,81 \\
& e_{t}=0,69 \div 0,77
\end{aligned}
$$

- sand/plasma coating

$$
\begin{aligned}
& e_{t}=0,58 \div 0,76 \\
& e_{t}=0,59 \div 0,71 \\
& e_{t}=0,58 \div 0,66 \\
& e_{t}=0,53 \div 0,63
\end{aligned}
$$

- iron oxides/steel

- For the sand/steel plate system, the impingement velocity was $\mathrm{w}_{1}=5.85 \mathrm{~m} / \mathrm{s}$, and the reflection velocity was $w_{2}=3.53 \mathrm{~m} / \mathrm{s}$ (Table 11). If the sand impingement velocity was the same as in the case of erosion of the aluminium plate, i.e., $w_{l}=5.73$, the linearly converted sand reflection velocity $w_{2}$ would equal $3.46 \mathrm{~m} / \mathrm{s}$, whereas the obtained value for the aluminium plate is $3.38 \mathrm{~m} / \mathrm{s}$ (Table 13), i.e., it is smaller - because aluminium is softer than steel.

For the plate with plasma-coated anti-erosion layer, the impingement velocity was $w_{1}=6.53 \mathrm{~m} / \mathrm{s}$, and the reflection velocity was $w_{2}=4.26 \mathrm{~m} / \mathrm{s}$ (Table 15 ). If the sand impingement velocity was the same as in the case of erosion of the steel plate, i.e., $w_{l}=5.85$, the linearly converted sand reflection velocity $w_{2}$ would equal $3.94 \mathrm{~m} / \mathrm{s}$, whereas the obtained value for the steel plate is $3.53 \mathrm{~m} / \mathrm{s}$ (Table 11). The postimpingement velocity would be lower because steel is softer than the anti-erosion coating.

\section{References}

1. I. G. Wright, M. Schütze, S.R. Paterson, P.F. Tortorelli, R.B. Dooley, Progress in prediction and control of scale exfoliation on superheater and reheater alloys (EPRI Inter. Conf. on Boiler Tube and HRSG Tube Failures and Inspections, San Diego, 2-5 November 2004)

2. R. Knödler, S. Straub, VGB PowerTech 10, (2008)

3. M. Pronobis, W. Wojnar, Eng. Fail. Anal. 32, 54-62 (2013)

4. Н. Кузниецов, Теплоэнергетика 4 (1955) [Teploenergetika 4 (1955)]

5. J. Świrski, Prace Instytutu Energetyki, Book 1, (Warszawa 1975)

6. M. Pronobis, Modernizacja kottów energetycznych [Modernisation of steam generators] (WNT Warszawa 2002)

7. E. Raask, Erosion wear in coal utilization (Hemisphere Publishing Corporation, ISBN 3540-18601-8, 1988)

8. V. Meuronen, Lappeenranta University of Technology, Research Papers 64, (Lappeenranta 1997)

9. Ansys Fluent. Computational Fluid Dynamics, Ansys Inc., USA, www.ansys.com.

10. Forder, Wear, 183-193 (1998)

11. T. Grant, W. Tabakoff, J Aircraft 12, 471-547 (1975)

12. K. Ahlert, Effects of Particle Impingement Angle and Surface Wetting on Solid Particle Erosion on AISI 1019 Steel. (M.S. Thesis, University of Tulsa. 1994)

13. J. K. Edwards, B. S. McLaury, S. A. Shirazi, Evaluation of alternative pipe bend fittings in erosive service. (In Proceedings of ASME FEDSM'00: ASME 2000 Fluids Eng. Division Summer Meeting, Washington D.C., June 2000) 